\title{
A Study on Castor Oil and Its Conversion into Biodiesel by Transesterification Method
}

\author{
Amita Nakarmi ${ }^{1}$ and Susan Joshi ${ }^{2}$ \\ ${ }^{1}$ Nepal Academy of Science and Technology, Lalitpur, Nepal. \\ ${ }^{2}$ Central Department of Chemistry, Tribhuvan University, Kathmandu, Nepal. \\ e-mail:ita_ameen@yahoo.com
}

\begin{abstract}
Castor (Ricinus communis) beans were subjected for the extraction of oil which contained $48 \%$ yield. The refined oil contained $0.8 \%$ free fatty acid (FFA) and $76.258 \mathrm{mg} \mathrm{KOH} / \mathrm{g}$ saponification value which showed that oil was very suitable for biodiesel production. Biodiesel can be synthesized by transesterification process using acid or base catalyst. The obtained oil and biodiesel was analysed by GC/MS and characterized for its use as fuel in compression ignition motors. From GC/MS, methyl esters content ( $6: 1$ molar ratio) was found to be about $88 \%$. The experiments were performed at variable condition such as methanol/oil molar ratio, different temperatures, types and concentration of catalysts used. The best condition for transesterification process was 9:1 methanol/oil molar ratio, $65^{\circ} \mathrm{C}$ and 1 weight $\%$ of $\mathrm{KOH}$. Product analysis was performed by ASTM/EN standards. The obtained biodiesel provided satisfactory values of density and saponification but its viscosity was very high. This situation can be corrected by mixing other methyl esters or mineral diesel for its use as diesel fuel.
\end{abstract}

Key words: castor oil, biodiesel, viscosity, transesterification

\section{Introduction}

Energy use is the most fundamental requirement for human existence for various purposes which can easily be facilitated by solar energy, hydropower, wind energy, fossil fuels and so on, but the major source of energy is fossil fuels (petrol, diesel, kerosene, ATF, etc) which are mostly used in different sectors. Fossil fuels are highly used in industrial, agricultural, automobiles, commercial and household usage. The consumption of fossil fuels has increased to a great extent (Rafaat et al. 2008). The total consumption of fossil fuels globally is 10 million tons per day while Nepal consumed fossil fuels up to $11.06 \%$ in 2009 which is illustrated in Fig. 1 and this rate is tremendously increasing day by day (WBI 2010). Due to high consumption of fossil fuel, it is expected that human societies will face an extreme possibility of an energy supply collapse in near future. In few decades, the deposition of fossil fuels will be depleted so it will impact on the majority use of this energy source (Prata et al. 2010).
Another inconvenient of use of fossil fuel as energy is related with environmental issues. As fossil fuels emit large amount of pollutants which are harmful for the environment as well as living creatures. So, the use of fossil fuels as energy resource is seen as having major environmental impacts. The major impacts of fossil fuels occur due to their consumption which produces different toxic gases like $\mathrm{CO}_{2}, \mathrm{SO}_{x}, \mathrm{CO}, \mathrm{NO}_{x}$ as well as some organic compounds such as aldehydes, monocyclic aromatic hydrocarbon (MAHs) and polycyclic aromatic hydrocarbons (PAHs). These harmful compounds damage the green house system of environment, cause global warming, pollution, acid rain and so on. Their toxicity on human health causes cancers, respiration problems, heart disease and so on. Therefore, the relevance of the search for other energy sources is noticeable as they will make possible to mitigate such problems. Hence, it is very necessary to find out other energy sources that can be obtained from biomass (from plant and animal fats). This biomass from both plants and animals absorb solar energy and store in the form of oil which can be used as fuel for 
the purpose of moving machines of different types of diesel vehicles. Most of the oils obtained from biomass nowadays can be used as an alternative source of energy as biodiesel (Prata et al. 2010).

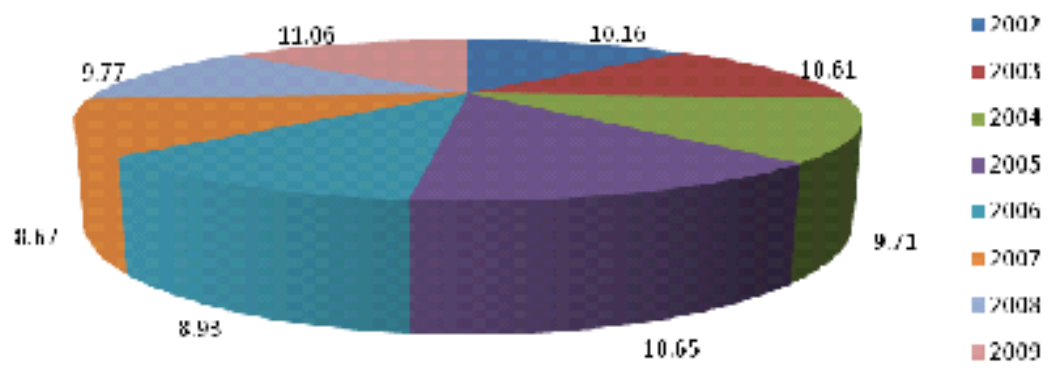

Fig. 1. Fossil fuels energy consumption (\% of total) in Nepal

Biodiesel is currently the most important alternative source of energy in European Union as it contributes in reducing the external dependence on fossil fuels. Similarly, it reduces the environmental impacts as it emits substantially lower quantities of most of the regulated pollutants than mineral diesel (Morais et al. 2010). So, biodiesel has been gaining worldwide popularity as an alternative energy source due to its high efficiency which can overcome petroleum crisis and increasing cost of petroleum diesel (Ferero 2004).

The natural resources like vegetable oils (edible and non-edible) and animal fats are good sources as alternative fuels for diesel engine but due to high viscosity, acid compositions and free fatty acids of oil create problems in diesel engines. So, various methods such as dilution, microemulsions, pyrolysis, catalytic cracking and transesterification have been considered to overcome the problem associated with direct use of oil. Of these alternatives, transesterification process

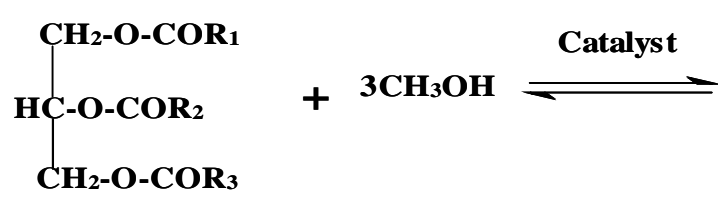

Methanol

Biodiesel has very similar physical properties just as fossil diesel fuel and even higher cetane number, which allows it to be used directly as substituted fuel in diesel engine without any modification or can be used as blending agent for diesel fuel (Bello et al. 2011).

Though biodiesel has many advantages as compared to petroleum diesel, its high production cost is playing has been proved to be the best option (Verma et al. 2007).

Transesterification is a reaction of an alcohol with an ester to form different types of alcohols and esters in the presence or absence of a catalyst. In the production of biodiesel, vegetable oil is in the form of triglyceride which reacts with a small chain alcohol (methanol, ethanol, propanol and so on) in the presence of homogeneous catalyst such as base $(\mathrm{KOH}, \mathrm{NaOH}$, $\left.\mathrm{CH}_{3} \mathrm{OK},\left(\mathrm{CH}_{3} \mathrm{O}\right)_{2} \mathrm{Ca}, \mathrm{CaO}\right)$ or acid $\left(\mathrm{HCl}, \mathrm{H}_{2} \mathrm{SO}_{4}, \mathrm{H}_{3} \mathrm{PO}_{4}\right)$ or heterogeneous catalyst as zeolites or biocatalyst as enzymes. Hence, the process is also known as alcoholysis, for methanol methanolysis and for ethanol, ethanolysis. The esters that formed in methanolysis are called as fatty acid methyl esters (FAMEs) and esters that formed in ethanolysis are fatty acid ethyl esters (FAEEs) (Roces et al. 2011). The reaction of transesterification can be illustrated as given below:

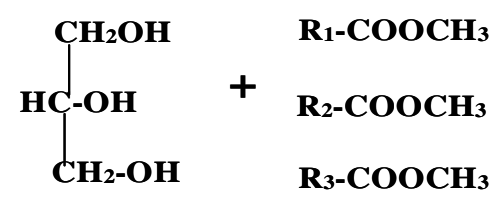

$$
\text { Glycerol Methyl esters }
$$

the primary barrier to its commercialization. So, many researchers focused on the utilization of lower cost feedstock such as waste cooking oil, greases, soap stocks, non-edible oil like Castor oil, algae and lower cost catalysts such as dolomite, and other calcium and magnesium ores to produce biodiesel. Glycerol, which is formed as a by-product from transesterification can 
be converted to promising commodity chemicals through chemo-selective catalysis such as selective oxidation, hydrogenolysis, catalytic dehydration, pyrolysis and gasification and so on. By these processes, glycerol can be converted to value- added product.

Castor oil obtained from castor beans contain about $45-60 \%$ of oil which can be used in production of paints, varnishes, lubricants, grease, hydraulic fluids, soaps, pharmaceuticals, cosmetics and so on. It contains $90 \%$ ricinoleic acid which is monounsaturated, 18- carbons fatty acid. This acid shows unusual character that it has acid group at first carbon, double bond at ninth carbon and a hydroxyl functional group on the twelfth carbon which cause unusually polar. Thus, this hydroxyl group makes the oil and ricinoleic acid highly viscous and valuable as chemical feedstock. Like any other vegetable oil, castor oil can be converted to biodiesel which can yield up to $98 \%$ (Chakrabati et al. 2008).

\section{Methodology}

\section{Collection of castor beans}

The castor fruits collected from Kritipur area were shade dried and separated beans from seed shell. Then they were ground into powdered form by using a simple grinder machine and stored in cool place.

\section{Oil extraction}

The castor oil was extracted by using a soxhlet extractor. About $500 \mathrm{ml}$ of hexane was poured in a round bottom flask and $100 \mathrm{~g}$ of ground castor beans was packed in a filter paper, placed in the thimble and fixed with a round bottom flask which was connected with a condenser. The fitted apparatus was then heated in a heating mantle to boil the solvent. When the solvent was boiled, the vapour rose through the vertical tube into condenser to the top and the vapour condensed, dripped into the thimble in the centre. The extractor seeped through the pores of the thimble and filled siphon tube where it flowed back down into the round bottom flask (Akpan et al .2006). The extraction prolonged to eight hours after which the resulting mixture in the round bottom flask was concentrated in rotator evaporator to recover the solvent from the extracted oil. The weight of the extracted oil was recorded.

The crude oil was refined by degumming, neutralization and bleaching process. In degumming process, the crude oil was treated with hot water to remove gums, hydrates, phosphates and other impurities, then it was neutralised with $0.1 \mathrm{~N} \mathrm{NaOH}$ to remove FFA and soap. Finally it was bleached with activated clay to remove colour, odour, impurities and residual soap.

\section{Transesterification}

About $25 \mathrm{ml}$ of oil was kept in three necked round bottom flask and heated to $65^{\circ} \mathrm{C}$. Then, calculated amount of methanol and catalyst $\left(\mathrm{KOH}\right.$ or $\left.\mathrm{H}_{2} \mathrm{SO}_{4}\right)$ were added with stirring system. The experiment prolonged for three hour and then the sample was monitored by running TLC to conform the completion of reaction. After cooling, two layers were separated by separatory funnel. The upper layer was methyl ester (biodiesel) while the lower layer was glycerol. The obtained methyl ester was purified by successive rinse with $2.5 \%(\mathrm{w} / \mathrm{w})$ sulphuric acid and distilled water. To avoid emulsion during washing process, $\mathrm{NaCl}$ solution was used. Then, the washed methyl ester was treated with anhydrous sodium sulphate to remove excess water. It was then filtered and dried by heating at low temperature $\left(60^{\circ} \mathrm{C}\right)$ for $30 \mathrm{~min}$.

\section{Product analysis}

The oil composition and methyl ester content were assayed by GC/MS (Shimadzu, Q.P.2010, Japan) from Water Engineering and Training Centre, Dillibazaar. The GC/MS used for analysis was provided with a FTD Detector, employing a silica capillary column of $30 \mathrm{~m}$ length, $0.32 \mathrm{~mm}$ ID, and $0.25 \mu \mathrm{m}$ film thickness. Heptane was used as solvent, and the carrier gas was helium at a flow rate of $0.96 \mathrm{ml} / \mathrm{min}$. The injector temperature was kept at $280^{\circ} \mathrm{C}$; the ion source temperature was $200^{\circ} \mathrm{C}$, column oven temperature $40^{\circ} \mathrm{C}$ and pressure $46.7 \mathrm{kPa}$.

The obtained oil and biodiesel was analyzed for characterization by ASTM method. The properties like density, specific gravity, methyl content, oil content, saponification value, acid value, FFA, refractive index were determined.

\section{Results and Discussion Analysis of oil}

Castor beans have high yield of oil up to $48 \%$. The gas chromatograph of castor oil has been presented in Fig. 2. The oil showed 28 compounds of them, six were major 9-tetradecenoic acid (myristoleic acid) was a major component of oil consists about $84.69 \%$. The retention time of it was 27.776 minutes. Other fatty acids have been presented in Table 1 . 


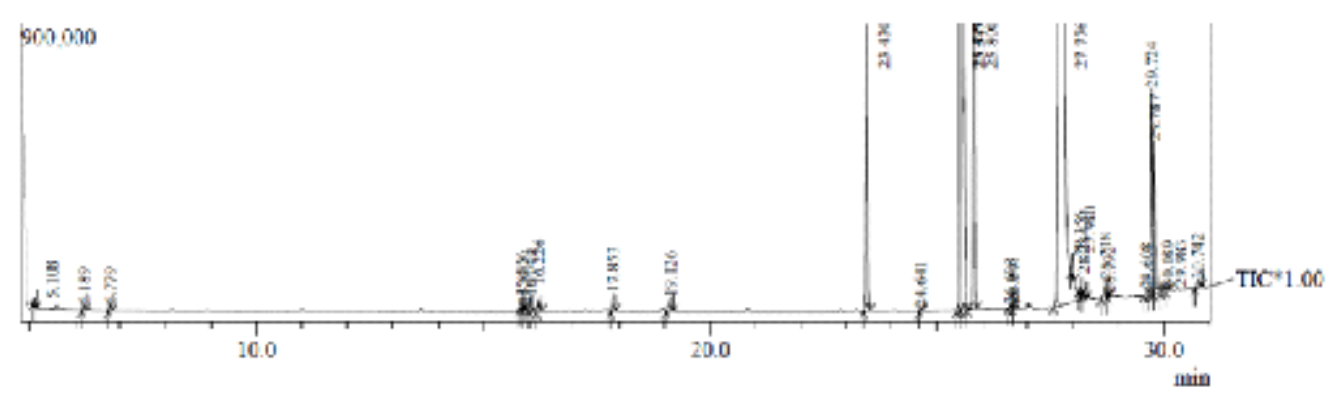

Fig. 2. Gas Chromatograph of castor oil

Table 1. Typical fatty acids in castor oil

\begin{tabular}{c|c|c|c|c|c}
\hline S.N. & Fatty acids & Mol formula & Mol Wg & $\begin{array}{c}\text { RT } \\
\text { (min) }\end{array}$ & $\begin{array}{c}\text { Area } \\
\%\end{array}$ \\
\hline 1 & Palmatic acid & $\mathrm{C}_{16} \mathrm{H}_{32} \mathrm{O}_{2}$ & 256 & 23.43 & 1.43 \\
2 & Linoliec acid & $\mathrm{C}_{18} \mathrm{H}_{32} \mathrm{O}_{2}$ & 280 & 25.5 & 5.18 \\
3 & Stearic acid & $\mathrm{C}_{18} \mathrm{H}_{36} \mathrm{O}_{2}$ & 284 & 25.4 & 1.97 \\
4 & Oleic acid & $\mathrm{C}_{18} \mathrm{H}_{34} \mathrm{O}_{2}$ & 282 & 25.547 & 4.9 \\
5 & Myristeric acid & $\mathrm{C}_{14} \mathrm{H}_{26} \mathrm{O}_{2}$ & 226 & 27.776 & 84.69 \\
6 & Honanoic acid & $\mathrm{C}_{1} \mathrm{H}_{16} \mathrm{O}_{3}$ & 172 & 29.787 & 0.84 \\
\hline
\end{tabular}

Myristoleic acid, which was found to be the major component in this oil, has not yet been reported in any paper so far. Moreover, ricinoleic acid which was reported as a major component of castor oil in many papers was not found in this oil. This variation may be due to change in climate, different variety of seeds or different location.

\section{Properties of oil}

The properties of the oil were slightly changed from the reported values. The oil was highly acidic and viscous. The saponification value was lower value than reported value. The GCMS report and saponification value showed that the molecular weight of the oil was extremely high from the expected value 180.33 mg KOH-gsample ${ }^{-1}$ (Akpan et al. 2006). The FFA value was $0.8064 \%$ while reported value is $3.4 \%$ (Jumat et al. 2010).

\section{Table 2. Castor oil properties}

\begin{tabular}{|c|c|c|c|c|}
\hline S.N. & Prop erties & Cruile on & Refined oil & Reported vahue \\
\hline 1 & Density $\left(\mathrm{kg}^{\prime} / \mathrm{m}^{2}\right)$ at $1 \mathrm{~s}^{\circ} \mathrm{C}$ & 917.3 & 917.3 & 961.20 \\
\hline 2 & S pecific gravity & 0.92 & 0.92 & 0.96 \\
\hline 3 & $V$ is cosity $(c S t)$ & 326.08 & 282.61 & 258.01 at $40^{\circ} \mathrm{C}$ \\
\hline 4 & Mois ture content & $1.75 \%$ & $1.003 \%$ & $0.2 \%$ \\
\hline 5 & Oil content & $48 \%$ & $48 \%$ & $45-60 \%$ \\
\hline 6 & A cid vahe (mgKOH-g'sample ${ }^{-1}$ ) & 2.629 & 1.566 & 1.09 \\
\hline 7 & Free fatty acid $\%$ & 1.354 & 0.8064 & 3.4 \\
\hline 8 & S aponification vahe (mgKOH -gample ${ }^{-1}$ ) & 79.159 & 76.258 & 180.33 \\
\hline 9 & $\mathbf{P}_{H}$ & 4 & 3.96 & 6.34 \\
\hline 10. & Refractive index & 1.479 & 1.476 & $1.476-1.479$ \\
\hline 12. & Colour & yellow & yellow & yellow \\
\hline
\end{tabular}

\section{Analysis of biodiesel}

The experiment for production of biodiesel was done with two types of catalysts such as $\mathrm{H}_{2} \mathrm{SO} 4$ as acid catalyst and $\mathrm{KOH}$ as base catalyst. Different operations were done with variations such as types and concentration of catalysts, methanol/oil ratio and temperature influence. 
The reaction time and agitation rates (high speed) were fixed as common parameters in all experiments.

Types and concentration of catalyst influence Different concentrations of $\mathrm{H}_{2} \mathrm{SO} 4$ and $\mathrm{KOH}$ were subjected in the experiment to analyze the influence on methyl esters content.

Table 3. Methyl ester content as function of catalyst type and concentration catalyst.

(Reaction conditions: methanol/oil molar ratio, 9:1; temperature, $65^{\circ} \mathrm{C}$; time, $3 \mathrm{hrs}$ )

\begin{tabular}{c|c|c}
\hline Type of catalyst & $\begin{array}{c}\text { Concentration } \\
\text { of catalyst } \\
\text { (w/w } \% \text { ) }\end{array}$ & $\begin{array}{c}\text { Methyl Ester } \\
\text { content } \\
\text { (w/w } \% \text { ) }\end{array}$ \\
\hline $\mathrm{H}_{2} \mathrm{SO}_{4}$ & 2 & 6.28 \\
& 3 & 8.29 \\
$\mathrm{KOH}$ & 4 & 6.78 \\
& 0.5 & 91.05 \\
& 1 & 92.01 \\
\hline
\end{tabular}

Table 3 showed that the transesterification reaction of castor oil under the study was more favourable with basic catalyst than acidic. Because the oil has low value of FFA so the use of acidic catalyst shows insignificant improvement of the process. The methyl ester content increased from concentration of basic catalyst from 0.5 to $1 \%(\mathrm{w} / \mathrm{w})$ but slight decrease from 1 to $1.5 \%(\mathrm{w} / \mathrm{w})$. In general, as the catalyst concentration increased, the conversion of triglyceride also increased (Leung et al. 2010). Because an insufficient catalyst concentration results in an incomplete conversion of triglyceride into methyl ester to participate in the production of more soap and so reduction in production of ester (Eevera $e t$ al. 2009). In acidic catalyst, the production of ester was nearly negligible.

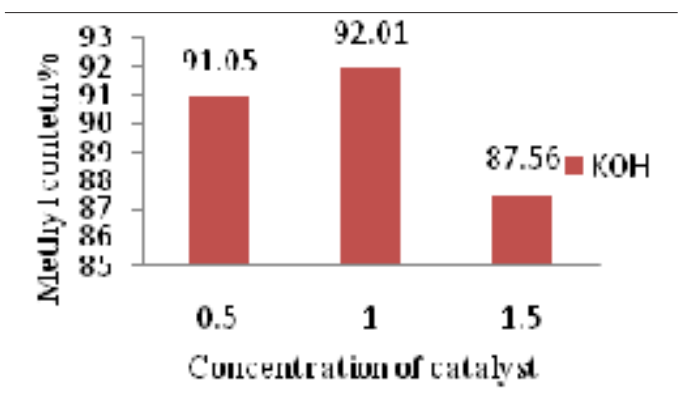

Fig. 3. Concentration of base catalyst influence in the production of biodiesel

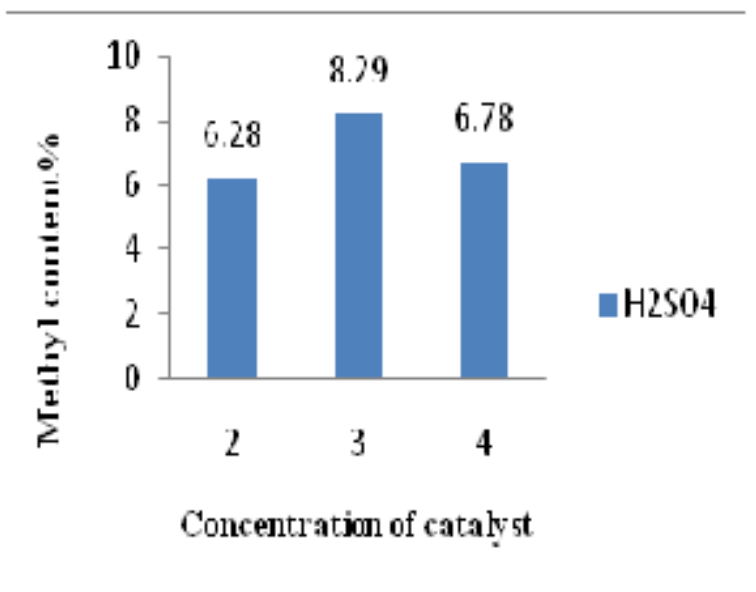

Fig. 4. Concentration of acid catalyst influence in the production of biodiesel

Figures 3 and 4 of methyl ester \% vs concentration of catalyst showed the reaction was extremely enhanced with base catalyst compared to acid.

\section{Methanol/Oil molar ratio}

The methanol/oil molar ratio is very important parameter for the production of methyl ester both in catalytic and non- catalytic reaction. Normally, transesterification requires 3 moles of alcohol for one mole of triglyceride to form three moles of fatty acid esters and one mole of glycerol (Mathiyazhagan et al. 2011). In alkaline catalysed process, the yield of methyl ester increases with an increase in alcohol/oil ratio as the equilibrium shift towards the product (Verma et al. 2007). Methanol/ oil molar ratio is also associated with the type of catalyst used. In general acid catalysed process requires high molar ratio than base catalysed process as shown in Table 4.

Table 4. Methanol/Oil molar ratio influence (Reaction conditions: temperature, $6^{\circ} \mathrm{C}$; time, $3 \mathrm{hrs}$ )

\begin{tabular}{c|c|c}
\hline $\begin{array}{c}\text { Methanolioil ratio } \\
\text { (mol:moI) }\end{array}$ & Catalyst & $\begin{array}{c}\text { Methyl Ester } \\
\text { content } \\
\text { (w/w \%) }\end{array}$ \\
\hline $6: 1$ & $\mathrm{H}_{2} \mathrm{SO}_{4}$, & 3.58 \\
$9: 1$ & $3 \mathrm{w} / \mathrm{w} \%$ & 6.29 \\
$12: 1$ & & 6.21 \\
$6: 1$ & $\mathrm{KOH}$, & 88.09 \\
$9: 1$ & $1 \mathrm{w} \%$ & 92.01 \\
$12: 1$ & & 90.31 \\
\hline
\end{tabular}




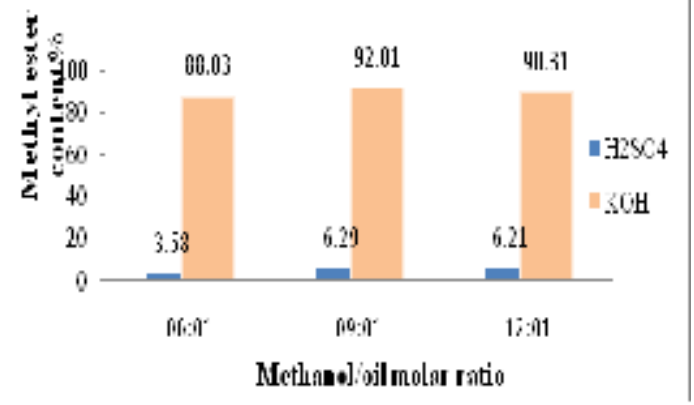

Fig. 5. Molar ratio influence in the production of biodiesel

Figure 5 and Table 4 showed that when the molar ratio increased from 6:1 to 9:1 in both catalysts, the methyl ester content also increased but on increasing molar ratio 12:1, there was no significant change was shown by acidic catalysis while it slightly decreased in methyl esters content in basic catalysis. Because the higher alcohol molar ratio interfered in the separation of glycerol due to high solubility. Again on excess use of alcohol, it seemed to favour conversion of di- to monoglyceride but there was also slight recombination of esters and glycerol to mono-glycerides as their concentration kept on increasing on the course of the reaction than in the reaction of lower molar ratio. In basic catalysis, this effect can be seen because the reaction was fast while in acidic catalysis, the effect was no apparently seen due to the low rate of reaction (Encinar et al. 2005).

\section{Temperature influence}

The transesterification of castor oil with methanol was carried out at $60,65,70^{\circ} \mathrm{C}$ in order to determine the temperature influence on the methyl ester production.

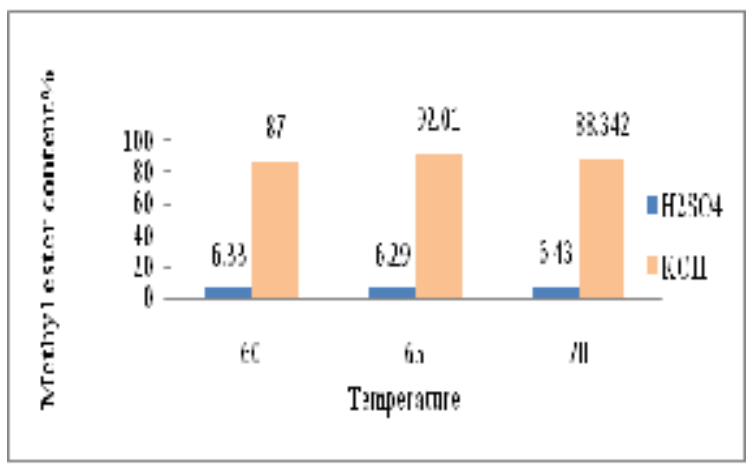

Fig. 6. Temperature influence in the production of biodiesel

Table 5. Temperature influence

(Reaction conditions: temperature, $6^{\circ} \mathrm{C}$; time, $3 \mathrm{hrs}$ )

\begin{tabular}{c|c|c}
\hline Temperature ('C) & Catalyst & $\begin{array}{l}\text { Methyl Ester } \\
\text { content (w/w } \%)\end{array}$ \\
\hline 60 & $\mathrm{H}_{2} \mathrm{SO}_{4}$ & 6.33 \\
65 & $3 \mathrm{w}^{\circ} \%$ & 6.29 \\
70 & & 6.43 \\
60 & $\mathrm{KOH}$ & 87.00 \\
65 & $1 \mathrm{w} \%$ & 92.01 \\
70 & & 88.342 \\
\hline
\end{tabular}

The optimized temperature for transesterification was $65^{\circ} \mathrm{C}$ (the boiling point of methanol is $64.7^{\mathrm{O}} \mathrm{C}$ ). Below and above this temperature, the yield of methyl ester was low. Because at lower temperature, the reaction was not completed and at high temperature, methanol vaporizes and burn. So, decomposition of solvent results in ineffective conversion of oil to methyl ester. The higher temperature may also cause deactivation of catalyst so incompletion of reaction might occur.

\section{Product Analysis}

Gas chromatogram of biodiesel is given in Fig. 7. The biodiesel consists of $88 \%$ methyl ester (6:1) with 6 compounds in Fig. 7.

Chromatogran 69 (Ess) C: GCMSsolution'Data Project Watural Resource New' 69 (Ess). ogi

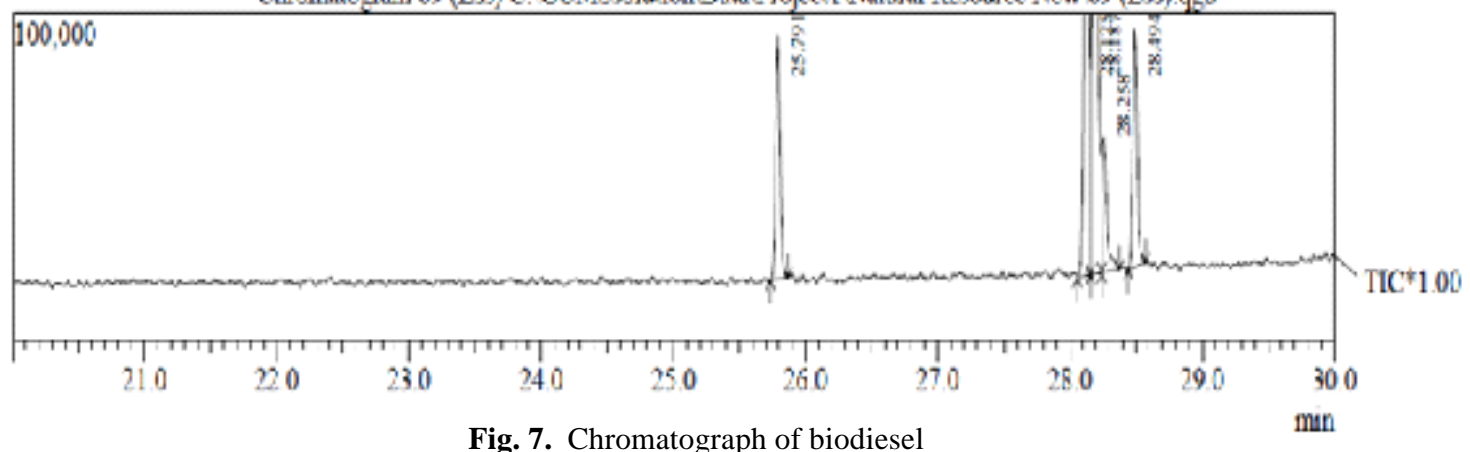


Table 6. Composition of methyl ester

\begin{tabular}{l|l|c|c|c|c}
\hline S.N & Methyl ester & $\begin{array}{c}\text { Molecular } \\
\text { formula }\end{array}$ & $\begin{array}{c}\text { Molecular } \\
\text { weight }\end{array}$ & Retention time & Area\% \\
\hline 1 & Methyl palmitate & $\mathrm{C}_{17} \mathrm{H}_{34} \mathrm{O}_{2}$ & 270 & 9.86 & 9.86 \\
2 & Methyl linoleate & $\mathrm{C}_{19} \mathrm{H}_{34} \mathrm{O}_{2}$ & 294 & 30.25 & 30.25 \\
3 & Methyl octa-9-enoate & $\mathrm{C}_{19} \mathrm{H}_{36} \mathrm{O}_{2}$ & 296 & 32.76 & 32.76 \\
4 & Methy1 9,10 & $\mathrm{C}_{15} \mathrm{H}_{2} \mathrm{O}_{2}$ & 282 & 5.38 & 5.38 \\
5 & methylenthe xadecanoate & $\mathrm{C}_{19} \mathrm{H}_{35} \mathrm{O}_{2}$ & 298 & 9.78 & 9.78 \\
6 & Methyl stereate & $\mathrm{C}_{10} \mathrm{H}_{15} \mathrm{O}_{3}$ & 116 & 11.97 & 11.97 \\
\hline
\end{tabular}

\section{Properties of biodiesel}

The properties of biodiesel were analyzed according to ASTM Standards presented in Table 7.

Table 7. Properties of biodiesel

\begin{tabular}{|c|c|c|c|c|}
\hline SN. & Properties & Biodiesel & Mineral Diesel & ASTM Std. \\
\hline 1 & Methyd ester content \% & $88(6: 1), 92(9: 1)$ & - & 97 \\
\hline 2 & Density $\left(\mathrm{kg}^{\prime}\left(\mathrm{m}^{2}\right)\right.$ at $15^{\circ} \mathrm{C}$ & 900 & 850 & $860-890$ \\
\hline 3 & Specific gavity & 0.9 & 0.85 & $0.86-0.89$ \\
\hline 4 & Viscosity ( $\mathrm{CSt})\left(100^{\circ} \mathrm{C}\right.$ & 20.62 & 3.2 & $1.9-6.0$ \\
\hline 5 & Moisture content \% & 0.37 & - & 0.05 \\
\hline 6 & $\begin{array}{l}\text { Saporific ation value } \\
\text { (mgKOH- gampample }\end{array}$ & 88.878 & - & - \\
\hline 7 & Refractive index & 1.461 & - & - \\
\hline
\end{tabular}

Methyl ester content at 6:1 ratio was $88 \%$ while for 9:1 ratio it was $92 \%$ which are near to ASTM limits. The density and specific gravity were key properties of fuel which directly affect the engine performance. The denser fuel has greater mass which influences in the engine output. The density and specific gravity of the biodiesel found to be within the limits.

Viscosity is another parameter of the fuel which depends on the flow of its liquid. Higher viscosity is a major problem of biodiesel in diesel engines (Akpan et al. 2006). The high value of viscosity of fuel causes depositions on engine which effect on its function. Though the viscosity of oil has been decreased up to 93\% after conversion to biodiesel but this value is still high as compared to reported value. Thus, the biodiesel cannot be directly used in diesel engine. To minimize the viscosity of fuel, it can be used by blending with other methyl ester or mineral diesel up to 10 to $20 \%$.
Moisture content can cause microbial growth that leads to tank corrosion. The water content is out of limit.

Saponification value shows average molecular weight of a sample. This value slightly increases from the value of oil due to formation of methyl ester.

\section{Acknowledgements}

The authors are grateful to University Grant Commission, Sanothimi, Bhaktapur for providing financial support for this study. We are thankful to the Central Department of Chemistry, Tribhuvan University, Kritipur for providing necessary facilities for this study.

\section{References}

Akpan, U. G., A. Jimoh and A. D. Mohammed. 2006. Extraction, characterization and modification of castor seed oil. Department of Chemical Engineering, Federal University of Technology, Minna P.M.B. 65, Niger State, Nigeria. 
Bello, E.I. and A. Makanju. 2011. Production, characterization and evaluation of castor oil biodiesel as alternative fuel for diesel engines. Emerging Trends in Engineering and Applied Science 2: 525-530.

Chakrabati, M. H. and R. Ahmad. 2008. Transesterification studies on castor oil as a first step towards its use in biodiesel production. Botany 40: 1153-1157.

Eevera, T., K. Rajendran and S. Saradha. 2009. Biodiesel production process optimization and characterization to assess the suitability of the product for varied environmental conditions. Renewable Energy 34: 762-765.

Encinar, J. M., J. F. González and A. R. Rodríguez. 2005. Biodiesel from used frying oil. variables affecting the yields and characteristics of the biodiesel. Industrial \& Engineering Chemistry Research 44: 5491-5499.

Jumat, S., D.A.M. Noor, A.T. Narizawati, M.Y.M. Firdau and A. Noraishah. 2010. Fatty acid composition and physiecochemical properties of malaysian castor bean Ricinus communis L.seed oil. Sains Malaysian 39(5):761-764.

Leonor, C.L.B. 2004. Biodiesel from castor oil: a promising fuel for cold weather. Department of Hydraulic, Fluids and Thermal Sciences, Francisco de Paula Santander University, Colombia.

Leung, D. Y. C., X. Wu and M. K. H. Leung. 2010. A review on biodiesel production using catalyzed transesterification. Applied Energy 87: 1083-1095.
Mathiyazhagan M. and A. Ganapathi. 2011. Factors affecting biodiesel production: review article. Plant Biology 1: 01-05.

Morais, S., S. Caoto, A. A. Martins and T. M. Mata. 2010. Designing eco- efficient biodiesel production processes from waste vegetable oils. Computer Aided Process Engineering 28: 253-258.

Prata, B. de A., J.B.F. Arruda and G.C Barroso. 2010. A petri nets approach for simulation and control of castor bean biodiesel supply chain. Management and Business Resource 5: 6-17.

Refaat, A.A., N.K. Attia, H.A. Sibak, S.T. El Sheltawy and G.I. El Diwani. 2008. Production optimization and quality assessment of biodiesel from waste vegetable oil. Environmental Science and Technology 5: 75-82.

Roces, S. A., R. Tan, F. Jose, T. DaCruz, S. C. Gond and R. K. VeraCruz. 2011. Methanolysis of jatropha oil using conventional heating. Chemical Engineering 11(1): 54-59.

Verma, M. N. and G. Madras. 2007. Synthesis of biodiesel from castor oil and linseed oil in supercritical fluids. Industrial \& Engineering chemistry Research 46(1): 1-6.

World Bank Indicator, Fossil fuel energy consumption (\% of total) in Nepal. 2010 [online] (http// www.fossilfuels.com/fossil fuel consumption in Nepal) (accessed 20 September 2012). 